\title{
Increased release and activity of matrix metalloproteinase-9 in patients with mandibuloacral dysplasia type A, a rare premature ageing syndrome
}

Lombardi F, Fasciglione GF, D'Apice MR, Vielle A, D'Adamo M, Sbraccia P, Marini S, Borgiani P, Coletta M, Novelli G. Increased release and activity of matrix metalloproteinase-9 in patients with mandibuloacral dysplasia type A, a rare premature ageing syndrome. Clin Genet 2008. (C) Blackwell Munksgaard, 2008

Mandibuloacral dysplasia type A (MADA; OMIM 248370), a rare disorder caused by mutation in the $L M N A$ gene, is characterized by post-natal growth retardation, craniofacial and skeletal anomalies (mandibular and clavicular hypoplasia, acroosteolysis, delayed closure of cranial sutures, low bone mass and joint contractures), cutaneous changes and partial lipodystrophy. Little is known about the molecular mechanisms by which LMNA mutations produce bone alterations. An altered bone extracellular matrix (ECM) remodelling could play a pivotal role in this disorder and influence part of the typical bone phenotype observed in patients. Therefore, we have focused our investigation on matrix metalloproteinases (MMPs), which are degradative enzymes involved in ECM degradation and ECM remodelling, thus likely contributing to the altered bone mineral density and bone metabolism values seen in five MADA patients. We evaluated the serum levels of several MMPs involved in bone development, remodelling and homeostasis, such as MMP-9, $-2,-3,-8$ and -13 , and found that only the $82 \mathrm{kDa}$ active enzyme forms of MMP-9 are significantly higher in MADA sera compared with healthy controls $(n=16)$. The serum level of MMP-3 was instead lower in all patients. No significant differences were observed between controls and MADA patients for the serum levels of MMP-2, -8 and -13 and of tissue inhibitor of metalloproteinase 2, a natural inhibitor of MMP-9. Similarly, normal serum levels of tumour necrosis factor alpha (TNF- $\alpha$ ), interleukin (IL)-6 and IL-1 $\beta$ were detected. These data suggest a possible involvement of MMP-9 in MADA disease, underlying the potential use in diagnosis and therapy.

\author{
F Lombardi ${ }^{a *}$, GF Fasciglione ${ }^{b_{*}}$, \\ MR D'Apice ${ }^{a}$, A Vielle ${ }^{a}$, \\ M D'Adamo', P Sbracciac, \\ S Marini ${ }^{b}$, P Borgiani $^{\mathrm{a}}$, M Coletta $^{\mathrm{b}}$ \\ and G Novelli ${ }^{\mathrm{a}, \mathrm{d}}$ \\ aDepartment of Biopathology and \\ Diagnostic Imaging, 'Department of \\ Experimental Medicine and Biochemical \\ Sciences, and ${ }^{\mathrm{C}}$ Department of Internal \\ Medicine, University of Rome 'Tor \\ Vergata', Rome, Italy, and 'Department of \\ Cardiovascular Medicine, University of \\ Arkansas for Medical Sciences, \\ Little Rock, AR, USA
}

*These authors have equally contributed to this work.

\begin{abstract}
Key words: bone remodelling laminopathies - mandibuloacral dysplasia - MMPs
\end{abstract}

Corresponding author: Giuseppe Novelli, PhD, Department of Biopathology and Diagnostic Imaging, University of Rome 'Tor Vergata', Via Montpellier 1, 00133 Rome, Italy.

Tel.: +3906 20900664/665; fax: +3906 20900669; e-mail: novelli@med.uniroma2.it

Received 8 January 2008, revised and accepted for publication 10 April 2008
Mandibuloacral dysplasia type A (MADA; OMIM 248370) is a very rare multisystemic autosomal recessive disorder belonging to the heterogeneous group of diseases collectively called primary laminopathies. MADA patients are characterized by several features including post-natal growth retardation along with typical skeletal abnormalities such as hypoplasia of the mandible and clavicles, shortening of distal phalanges, de- layed closure of the cranial sutures and joint contractures; osteoporosis; cutaneous change such as atrophic skin; partial alopecia; mottled hyperpigmentation; partial lipodystrophy and, finally, progeroid appearance $(1,2)$. Some of these patients are hyperinsulinemic and insulin resistant with impaired glucose tolerance or overt diabetes mellitus. This disorder is caused by homozygosity or compound heterozygosity for different mutations 
in the $L M N A$ gene encoding for A-type lamins, lamin A/C (3-5). A-type lamins, expressed in most differentiated tissues, are intermediate filament proteins (6), which are the major components of the nuclear lamina, together with B-type lamins. They form a meshwork located between the inner nuclear membrane and the chromatin, so they play a fundamental role in the maintenance of the size and shape of the nucleus (7) and in several nuclear processes such as transcription, chromatin organization and DNA replication. Mutations in the $L M N A$ gene can bring about cardiac and skeletal muscle diseases, lipodystrophy and premature ageing phenotypes (8-10). Mandibuloacral dysplasia (MAD) is also due to a mutation in another gene (i.e. ZMPSTE24) that encodes for a zinc metalloproteinase involved in posttranslational proteolytic cleavage of carboxyterminal residues of farnesylated prelamin A to form mature lamin A (11). This mutation determines MAD with type B lipodystrophy (OMIM 608612). The patients show generalized loss of subcutaneous fat involving the face, trunk, and extremities and metabolic complications. Moreover, they have several facial and skeletal anomalies very similar to the MADA patients.

Deficiency of Zmpste24 in mice (Zmpste24-/- $)$ phenocopies features MAD like such as accumulation of prelamin A. The most striking pathological phenotype is multiple spontaneous bone fractures, akin to those occurring in mouse models of osteogenesis imperfecta; moreover, they show a significant reduction in cortical and trabecular bone volumes (12). The osteogenesis requires the carefully coordinated interplay of many factors, and in this regard, proteolytic remodelling of extracellular matrix (ECM) is a condition sine qua non (13). Bone also continuously undergoes remodelling through a dynamical balance between resorption and deposition achieved by osteoclasts and osteoblasts, respectively. In this framework, a very important role in bone development, remodelling and homeostasis (14) is played by matrix metalloproteinases (MMPs), which are a family of zinc-dependent neutral endopeptidases characterized by their ability to degrade ECM components and break down the basement membrane. This influences bone development, remodelling and homeostasis (14). In general, MMPs' proteolytic activity is regulated at three main levels: transcription, proenzyme activation, and inhibition, which must be balanced in a concerted fashion to avoid undesired degenerative processes. MMP expression is cell and tissue specific and can be induced by various signals, such as inflammatory cytokines, growth factors and the extracellular MMP inducers
$(15,16)$. Furthermore, the expression of various MMPs can be upregulated or downregulated by integrin-derived signals, ECM proteins, physical stress, and changes in cell shape (17).

MMPs are synthesized as inactive zymogens, pro-MMPs, which are usually activated in the pericellular space by other MMPs or serine proteinases through a proteolytic cleavage within MMP pro-domains. Their production and activity are usually very low in normal adult resting tissues, and with some exceptions, they are maintained at virtually undetectable levels by tissue inhibitors of metalloproteinase (TIMPs) and non-specific proteinase inhibitors $(18,19)$. The balance between MMPs and their inhibitors is essential in many physiological conditions where rapid remodelling of ECM is required, and any alteration could lead to pathological conditions, such as cancer (20). However, their expression may become elevated during specific physiological processes (such as tissue remodelling during growth phases, pregnancy and parturition and in post-menopausal osteoporosis) and/or in many pathological conditions (e.g. chronic inflammatory processes and malignancy) (21). In fact, elevated serum levels of MMPs have been reported in polycystic kidney disease (22), multiple sclerosis (23), rheumatoid arthritis (24), and many different human tumours including carcinomas of the lung, colon, breast and prostate (25-28).

In this study, we have analysed, by quantitative and qualitative enzyme assays, the behaviour of several circulating MMPs in MADA patient's serum. We measured the serum concentrations of gelatinase A (MMP-2) and gelatinase B (MMP-9), stromelysin 1 (MMP-3), neutrophil collagenase (MMP-8), collagenase-3 (MMP-13) and finally TIMP-2. We also determined the serum level of several inflammatory cytokines. As a whole, it emerges that MMP-9 is likely to be involved in the pathophysiology observed in MADA patients and that inhibition of MMP-9 function might protect against the progressive development of osteoporosis observed in MADA patients. As a corollary, MMP-9 might be a suitable biomarker for validating new drugs in MADA and possibly in other laminopathies.

\section{Materials and methods}

Patients and serum samples

The study was performed on MADA patients previously characterized (3). We collected five patients (two males and three females) recruited in Italy between 2000 and 2007 with different age, ranging from 5 to 40 years (the median age was 
22.5 years). Four patients, homozygous for the $\mathrm{R} 527 \mathrm{H}$ mutation, showed acroosteolysis, craniofacial abnormalities, hypoplasia of clavicles, and type A lipodystrophy (3). There is no significant difference concerning the phenotypic severity between all examined patients, indicating the independence of this disorder by age and sex. One patient was compound heterozygous with the classical $\mathrm{R} 527 \mathrm{H}$ mutation and another missense mutation in exon 7 (V440M) (29). She showed an MADA-like phenotype with the absence of clavicular dysplasia and normal metabolic profiles associated with muscle hyposthenia and generalized hypotonia. Bone mineral density (BMD) was determined by dual-energy X-ray absorptiometry (DEXA) at the lumbar spine and femoral neck sites. All BMD results were expressed in $\mathrm{kg} / \mathrm{m}^{2}$ and as standard deviation from the mean of an age-matched and sex-matched population ( $Z$-score)

Parental or patient's informed consent was obtained. Blood samples were collected by a single venipuncture. After clotting, serum was separated by centrifugation at $1300 \mathrm{~g}$ for $15 \mathrm{~min}$ at $4^{\circ} \mathrm{C}$ and prepared in tubes without additive. Serum was divided into aliquots and stored at $-80^{\circ} \mathrm{C}$ until use. The control group was represented by 16 healthy volunteers, 8 females and 8 males with age ranging from 10 to 50 years. Furthermore, a group of eight post-menopausal osteoporotic women (age range 45-52 years) was used as a positive control. No therapy known to interfere with bone metabolism was administered at the time of the study. Serum samples were collected from all the study subjects in the morning after an overnight fasting.

\section{Substrate zymography}

Gelatin substrate zymography was used for the evaluation and characterization of serum proteinases. Serum sample $(1 \mu \mathrm{g}$ of proteins/lane; protein determination following Bradford [1976]) was mixed with a fivefold excess of sample buffer $(0.25 \mathrm{M}$ Tris, $0.8 \%$ sodium dodecyl sulphate (SDS), $10 \%$ glycerol and $0.05 \%$ bromophenol blue), and electrophoresis was run on $12 \%$ sodium dodecyl sulphate-polyacrylamide gel electrophoresis (SDS-PAGE) gels containing $1 \mathrm{mg} / \mathrm{ml}$ of gelatin, as described (30). Electrophoresis was performed at $200 \mathrm{~V} / 40 \mathrm{~mA}$ for each gel in $25 \mathrm{mM}$ Tris, $0.2 \mathrm{M}$ glycine, and $1 \%(\mathrm{w} / \mathrm{v})$ SDS running buffer, $\mathrm{pH} 8.2$, until the tracking dye reached the bottom of the gel. After electrophoresis, SDS from gels was removed by four 15-min washings in $2 \%$ Triton $\mathrm{X}-100$. The gelatin gels were then incubated at $37^{\circ} \mathrm{C}$ for $18 \mathrm{~h}$ in incubation buffer
(50 mM Tris- $\mathrm{HCl}$ buffer $\mathrm{pH} 7.6,0.15 \mathrm{M} \mathrm{NaCl}$, $10 \mathrm{mM} \mathrm{CaCl}_{2}, 2 \%$ Triton X-100). The gels were then stained with $0.5 \%$ Coomassie blue and destained in $10 \%$ acetic acid and $40 \%$ methanol until proteinase bands were clearly visible. Proteinase bands were further characterized by adding $20 \mathrm{mM}$ ethylenediaminetetraacetic acid (EDTA) or $0.3 \mathrm{mM}$ 1,10-phenanthroline (MMP inhibitors) or $1 \mathrm{mM}$ phenylmethylsulphonyl fluoride (PMSF) (serine proteinase inhibitor) to the incubation buffer. Protein markers (Bio-Rad, Hercules, CA) were used as molecular weight standards. The intensities and area of gelatinolytic activity have been measured and quantified by an image analysis software (IMAGEQUANT TL; Amersham Biosciences, Piscataway, NJ). An arbitrary unit (AU) scale was used, and results were statistically analysed.

\section{Western immunoblots}

Western blotting was carried out using the same serum sample to identify proteinases and their inhibitors $(1 \mu \mathrm{g}$ of proteins/lane; protein determination following Bradford [1976]). Each sample was mixed with a fivefold excess of sample buffer $(0.25 \mathrm{~mol} / 1$ Tris, $0.8 \%$ SDS, $10 \%$ glycerol and $0.05 \%$ bromophenol blue) and run on $12 \%$ SDS-polyacrylamide gel either after 2 min of boiling in presence of 2-mercaptoethanol. Gels were then transferred to nitrocellulose membrane (Amersham, Buckinghamshire, UK) in TRANSBLOT (Bio-Rad) using Towbin buffer $(25 \mathrm{mM}$ Tris, $192 \mathrm{mM}$ glycine, and 20\% methanol). Unspecific binding sites were blocked with 5\% dry low-fat milk in phosphate buffered saline (PBS) for $1 \mathrm{~h}$ at $37^{\circ} \mathrm{C}$; membranes were then washed once with PBS and further incubated overnight at $4^{\circ} \mathrm{C}$ with the right concentration of mouse monoclonal ( $1 \mathrm{mg} / \mathrm{ml}$; R\&D Systems, Minneapolis, MN) antibodies directed against human gelatinase A (MMP-2), human gelatinase B (MMP-9), human neutrophil collagenase (MMP-8), human collagenase-3 (MMP-13) and TIMP-2. Thereafter, three washes (5 min each) with PBS/Tween-20 $(0.2 \%)$ were performed, and membranes were then incubated with a $1 / 1000$ dilution of horseradish peroxidase-labelled goat anti-mouse antibodies (Bio-Rad) in PBS for $2 \mathrm{~h}$, followed by further washings (three washes, $5 \mathrm{~min}$ each) with PBS/ Tween-20 $(0.2 \%)$. The bands were visualized by incubation of the membrane (4-chloronaphtol $0.6 \mathrm{mg} / \mathrm{ml}$ and $\left.30 \% \mathrm{H}_{2} \mathrm{O}_{2} 0.6 \mu \mathrm{l} / \mathrm{ml}\right)$ or by using ECL detection systems (Amersham). Results were analysed by an image analysis software (IMAGEQUANT TL; Amersham Biosciences). An AU scale was used, and results were statistically analysed. 
Enzyme-linked immunosorbent assay quantification

The bone alkaline phosphatase (BALP) and serum cross-linked C-terminal telopeptide fragments of degraded type I collagen (CTX-I) considered bone remodelling markers were analysed in sera together with levels of MMP-2, -3, and -9 and of physiological inhibitors, TIMP-2. We also quantified the levels of cytokines, tumour necrosis factor alpha (TNF- $\alpha$ ), interleukin (IL)- 6 and IL$1 \beta$. Measurements were performed using a commercial enzyme-linked immunosorbent assay (ELISA) kit (BAP EIA Kit; Metra Quidel, San Diego, CA; Serum CTX-I EIA Kit, CrossLaps ${ }^{\circledR}$; Quidel, San Diego, CA; Quantikine Human/ Mouse/Rat MMP-2 total; R\&D Systems; Immunoassay Kit Human MMP-3; Invitrogen, Carlsbad, CA; Quantikine Human MMP-9 total; R\&D Systems; Human TIMP-2 ELISA Kit; RayBiotech, Inc., Norcross, GA; Immunoassay Kit Human TNF- $\alpha$ Ultra Sensitive; Invitrogen; IL-6 Kit ELISA, IL-1 $\beta$ ELISA; eBioscience, San Diego, CA) according to the manufacturer's instructions. All measurements were performed in duplicate. Both the MMP-2 and the MMP-9 assays are specific for pro- and active MMP-2 and 9. Serum samples were diluted in assay buffer standards and incubated in a microwell plate pre-coated with specific antibodies at room temperature. Any antigen present in the samples was bound to the wells, and the excess was removed by extensive washing. These antigens were then detected by a peroxidase-labelled antibody, and the amount of peroxidase was determined by the addition of tetramethyl benzidine substrate. Reactions were stopped by adding acid solution, and the absorbance was read at $450 \mathrm{~nm}$ in a microtitre plate spectrophotometer. Serum concentrations were determined from the corresponding standard curves run for each plate separately. A standard curve was obtained by using recombinant proteins.

\section{Statistical analysis}

A computer database containing all data measured from patients was created. These data were analysed using the STAT VIEW $512+$ program from Brain Power, Inc. (Calabasas, CA). Regression analysis, correlation test and Student's $t$-test have been used. All results are expressed as mean $\pm \mathrm{SD}$.

\section{Results}

\section{Bone metabolism}

MADA serum levels of C-telopeptides of type I collagen (CTX-I), a marker of bone resorption, were well above the pre-menopausal range $(0.68 \pm 0.07 \mathrm{ng} / \mathrm{ml})$. Nevertheless, patients showed normal serum levels of BALP (32.3 \pm $5.6 \mathrm{IU} / 1)$, considered a marker of bone formation. On the other side, our set of patients showed a very low BMD at lumbar spine ( $Z$-score $-1.77 \pm 0.14$ ) in comparison with the control group, as measured by DEXA, and the same was true for the femoral neck BMD ( $Z$-score $-3.4 \pm 0.23)$ (Table 1).

Table 1. Clinical and biochemical parameters of patients and controls

\begin{tabular}{|c|c|c|c|c|c|c|}
\hline & \multirow[b]{2}{*}{ Control } & \multirow[b]{2}{*}{ MADA } & \multirow[b]{2}{*}{ Osteoporotic } & \multicolumn{3}{|l|}{$\mathrm{p}$} \\
\hline & & & & $\begin{array}{l}\text { Control vs } \\
\text { MADA }\end{array}$ & $\begin{array}{l}\text { Control vs } \\
\text { osteoporotic }\end{array}$ & $\begin{array}{l}\text { MADA vs } \\
\text { osteoporotic }\end{array}$ \\
\hline $\operatorname{Sex}(M / F)$ & $7 / 9$ & $2 / 3$ & $0 / 8$ & - & - & - \\
\hline Age (years, range) & $10-50$ & $5-40$ & $45-52$ & - & - & - \\
\hline $\mathrm{BMI}\left(\mathrm{kg} / \mathrm{m}^{2}\right)$ & $24.38 \pm 0.7$ & $17.2 \pm 0.51$ & $22.9 \pm 0.49$ & $<0.01$ & NS & 0.05 \\
\hline BMD lumbar spine (Z-score) & $0.27 \pm 0.12$ & $-1.77 \pm 0.14$ & $-2.3 \pm 0.12$ & $<0.01$ & $<0.0005$ & NS \\
\hline BMD femoral neck ( $Z$-score) & $0.33 \pm 0.07$ & $-3.4 \pm 0.23$ & $-1.9 \pm 0.12$ & $<0.005$ & $<0.03$ & 0.05 \\
\hline BALP (IU/I) & $29.4 \pm 9.3$ & $32.3 \pm 5.6$ & $21.6 \pm 1.6$ & NS & $<0.03$ & $<0.02$ \\
\hline CTX-I (ng/ml) & $0.12 \pm 0.09$ & $0.68 \pm 0.07$ & $0.55 \pm 0.11$ & $<0.03$ & $<0.05$ & NS \\
\hline MMP-9 (ng/ml) & $0.6925 \pm 0.1335$ & $4.586 \pm 0.5296$ & $3.041 \pm 0.3415$ & $<0.0001$ & $<0.0001$ & NS \\
\hline MMP-2 (ng/ml) & $24.74 \pm 1.104$ & $27.82 \pm 3.993$ & NA & NS & - & - \\
\hline MMP-3 (ng/ml) & $5.154 \pm 0.7575$ & $1.818 \pm 0.9151$ & $7.495 \pm 0.9365$ & 0.0341 & 0.07 & 0.002 \\
\hline TIMP-2 (ng/ml) & $4.605 \pm 0.1281$ & $4.643 \pm 0.1198$ & NA & NS & - & - \\
\hline $\mathrm{TNF}-\alpha(\mathrm{pg} / \mathrm{ml})$ & $0.018 \pm 0.043$ & $0.0034 \pm 0.006$ & NA & NS & - & - \\
\hline $\mathrm{IL}-1 \beta(\mathrm{pg} / \mathrm{ml})$ & $0.5365 \pm 0.9979$ & $0.3344 \pm 0.6561$ & NA & NS & - & - \\
\hline IL-6 (pg/ml) & $1.855 \pm 0.4824$ & $3.683 \pm 4.028$ & NA & NS & - & - \\
\hline
\end{tabular}

BALP, bone alkaline phosphatase; BMD, bone mineral density; BMI, body mass index; CTX-I, C-terminal telopeptide fragments of degraded type I collagen; F, female; M, male; MADA, mandibuloacral dysplasia type A; MMP, matrix metalloproteinase; NA, not available; NS, not significant; IL, interleukin; TIMP-2, tissue inhibitor of metalloproteinase 2; TNF- $\alpha$, tumour necrosis factor alpha. 
Identification of proteinases in the serum samples

In all sera, different gelatin-degrading activities were observed, corresponding to molecular weights of $207,116,94,92,82$, and $62 \mathrm{kDa}$. In all MADA sera, we detected four forms (i.e. corresponding to $207,116,92$ and $82 \mathrm{kDa}$, respectively) that could be related to gelatinase $\mathrm{B}$ (MMP-9) corresponding to the molecular weights of the disulphide-linked homodimer, the complex with neutrophil gelatinase B-associated lipocalin (NGAL), pro-MMP-9 and active MMP-9, respectively. Conversely, in control serum, we detected (Fig. 1a) only the active forms at 92 and $82 \mathrm{kDa}$ (31). In the serum from MADA patients, the levels of the active form of MMP-9 were markedly enhanced, showing a considerable activity of this
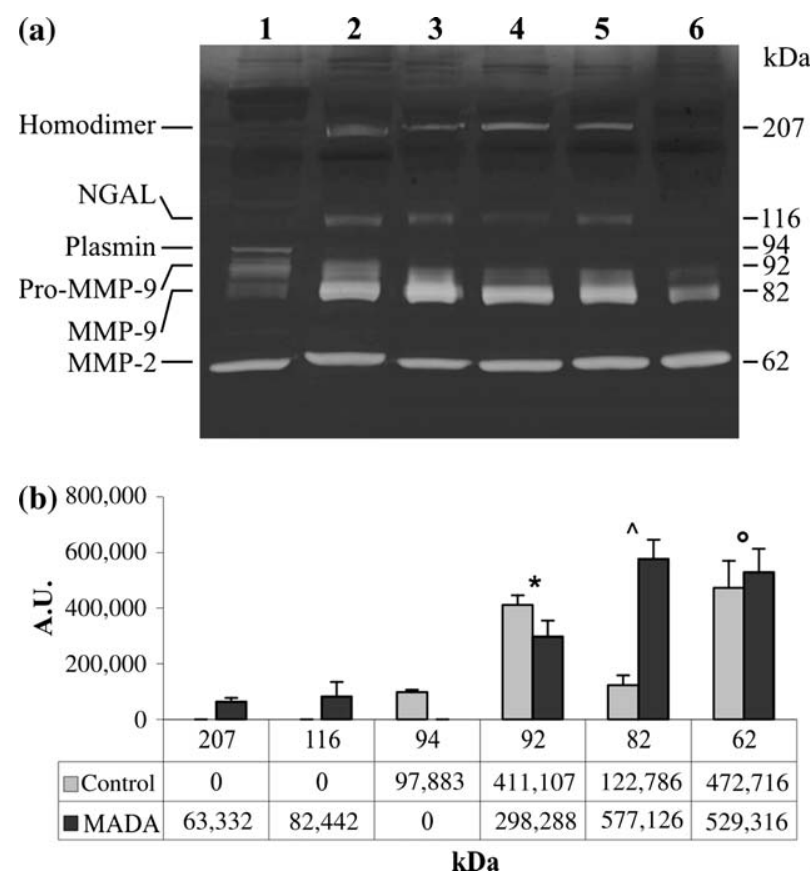

Fig. 1. (a) Gelatinolytic activity in serum samples. Gelatin substrate zymography of sera collected from MADA patients with $\mathrm{R} 527 \mathrm{H} / \mathrm{R} 527 \mathrm{H}$ (lanes 2, 3, 4, and 6) or $\mathrm{R} 527 \mathrm{H} / \mathrm{V} 440 \mathrm{M}$ genotypes (lane 5) matched with a healthy control (lane 1). Zymographic profile of lane 1 reflects that one identified in all 16 different sera collected from normal subjects. The latent, pro, and active forms of MMP-9 and the active form of MMP-2 are indicated on the left; molecular masses $(\mathrm{kDa})$ are indicated on the right. (b) Densitometric analysis of MMPs. The intensities of zymographic bands have been measured and quantified by an image analysis software (IMAGEQUANT TL; Amersham Biosciences). The mean of each band $\pm \mathrm{SD}$ is reported in a bar graph. The mean value of control is derived from normalized values of all 16 healthy controls. An arbitrary unit scale was used. $* \mathrm{p}<0.05$ control vs patients; $\hat{p}$ $<0.005$ control vs patients; ${ }^{\circ} \mathrm{p}=0.1$ control vs patients. MADA, mandibuloacral dysplasia type A; MMP, matrix metalloproteinase; NGAL, neutrophil gelatinase B-associated lipocalin. gelatinase with respect to the control serum (Fig. 1b). Proteinase activities corresponding to bands weighing about 207 and $116 \mathrm{kDa}$ were detected only in four MADA patients with a mean value of $63,332 \pm 13,382$ and $82,442 \pm 51,690$ AU, respectively (Fig. 1b). The band corresponding to the molecular weight of $62 \mathrm{kDa}$, corresponding to the active MMP-2, was present in all samples (control and MADA patients) with a similar or slightly higher activity in MADA sera with respect to the control ones (Fig. 1a,b). Most bands $(207,116,92,82$, and $62 \mathrm{kDa})$ were completely abolished when gels have been incubated in a buffer containing $10 \mathrm{mM}$ EDTA or $0.3 \mathrm{mM}$ 1,10-phenanthroline (MMP inhibitors), confirming that the activity should be confidently attributed to a metalloproteinase (data not shown). A proteolytic activity related to a $94 \mathrm{kDa}$ enzyme was present in $100 \%(97,883 \pm 8.645 \mathrm{AU})$ of control serum but never in samples from MADA patients (Fig. 1b). This activity was completely inhibited by $0.1 \mathrm{mM}$ PMSF in the incubation buffer, whereas no effect was observed upon addition of 1,10-phenanthroline or EDTA (data not shown), indicating that this activity should be instead related to a serine proteinase, probably the plasmin. Western blot experiments have been performed, employing antibodies against gelatinase A (MMP-2, molecular weight $72-62 \mathrm{kDa}$ ) and gelatinase B (MMP-9, molecular weight 92$82 \mathrm{kDa}$ ), to characterize the band seen by gelatin zymography analysis. Results obtained show the presence of multiple forms of MMP-9 enzyme in the serum from MADA patients, whereas in serum control, only the high-molecular weight form was found (Fig. 2a). The pattern of MMP-2 (both forms) was similar in all samples tested (data not shown), showing no correlation with the pathology.

To characterize the presence of other MMPs in the serum, we performed Western blots employing antibodies against neutrophil collagenase (MMP8 ) and collagenase-3 (MMP-13). Also in this case, we observed the two collagenases in all samples, and no significant differences were detected between MADA sera and control sera (Fig. 2b,c).

As shown in Fig. 3a, the values of total MMP-9 in sera from MADA patients range between 3.45 and $6.34 \mathrm{ng} / \mathrm{ml}$, with a mean concentration of $4.586 \pm 0.5296 \mathrm{ng} / \mathrm{ml}$, and they are significantly higher $(\mathrm{p}<0.0001)$ than the value of control serum (mean concentration $0.6925 \pm 0.1335 \mathrm{ng} /$ ml) (Fig. 3a). However, the values of total MMP-2 in sera from MADA patients were similar to the control ones (mean concentration $27.82 \pm 3.993$ vs $24.74 \pm 1.104 \mathrm{ng} / \mathrm{ml}, \quad \mathrm{p}=$ 0.3031) (Fig. 3b). Interestingly, plasma level of 
(a)

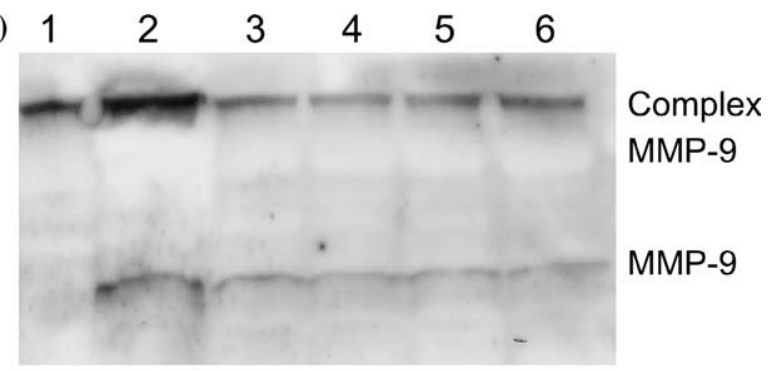

(b)

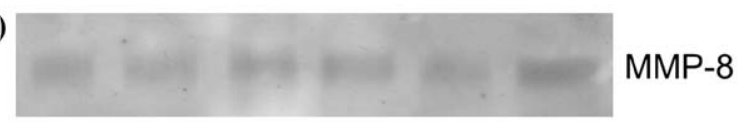

(c)

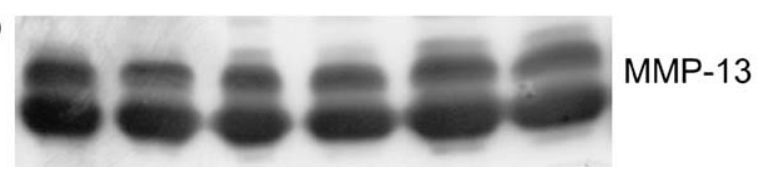

Fig. 2. (a) Western blot analysis of MMP-9 in total serum. MMP-9 was found primarily in its complex form in control sample (lane 1); complex and active MMP-9 were detected in mandibuloacral dysplasia type A (MADA) subject sample (lanes 2-5). (b and c) Representative Western blot of MMP-8 and -13 revealing the same pattern in all MADA and control serum samples. MMP, matrix metalloproteinase.

MMP-3 in MADA patients was significantly lower compared with the normal control (mean concentration $1.818 \pm 0.9151$ vs $5.154 \pm 0.7575 \mathrm{ng} / \mathrm{ml}$, $\mathrm{p}=0.0341$ ) (Fig. 3c, Table 1). There were no statistically significant differences between age and gender.

Moreover, we compared circulating values of MMP-9 and -3 in MADA patients with levels detected in a consecutive series of patients with osteoporosis analysed according to the same analytical protocol. Interestingly, the latter group showed higher MMP-9 levels with respect to healthy control, as expected, but much lower levels $(2.041 \pm 0.3415 \mathrm{ng} / \mathrm{ml})$ with respect to MADA patients. Furthermore, in osteoporotic patients, elevated MMP-3 (7.495 $\pm 0.9365 \mathrm{ng} /$ $\mathrm{ml}$ ) serum levels have been detected compared with the healthy control and MADA patients (data not shown).

The variation of enzymatic activity of MMP-9 in MADA patients outlined above was also compared with the amounts of tissue inhibitor of MMPs (i.e. TIMPs) and in particular TIMP-2. The total amount of TIMP-2 was found similar in all patients and controls, clearly indicating that the higher activity of MMP-9 was not related to a reduced level of natural inhibitors. The values, found by ELISA, ranged from $4.643 \pm 0.1198 v s$ $4.605 \pm 0.1281 \mathrm{ng} / \mathrm{ml}$ in all groups $(\mathrm{p}=0.8786)$ (Fig. 3d). Normal levels of cytokines such as
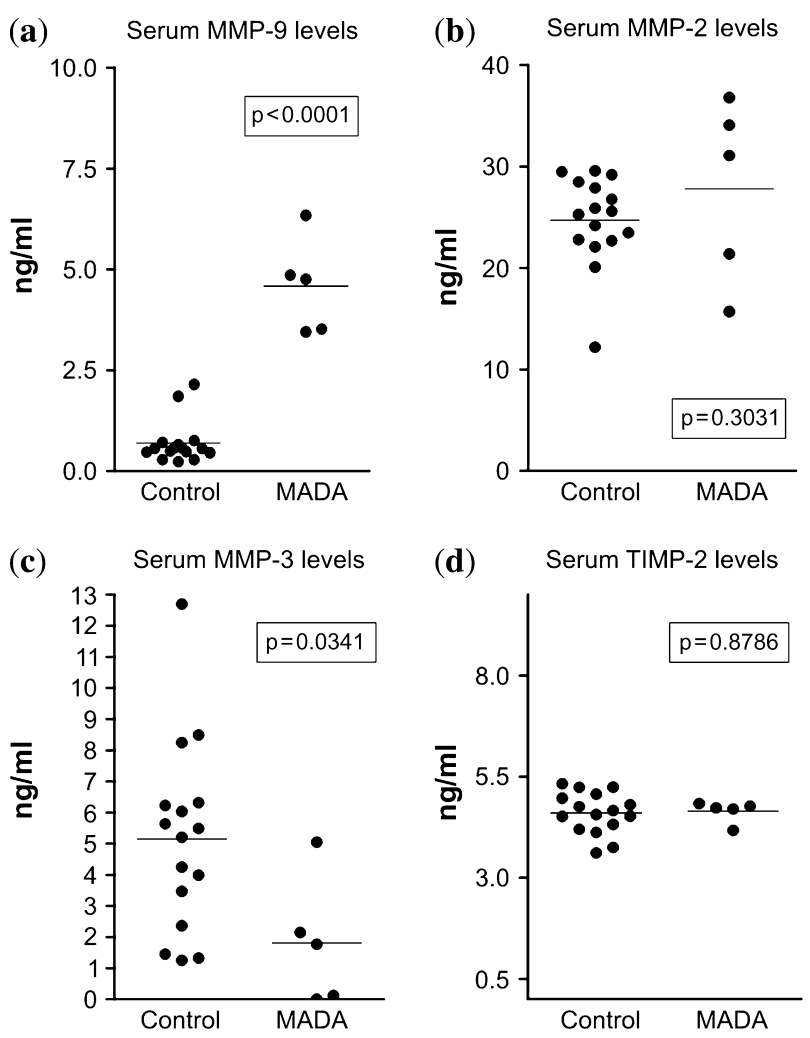

Fig. 3. Statistical analysis of the distribution of total serum level of MMP-9, -2, and -3 and TIMP-2 in MADA patients $(n=5)$ and healthy controls $(n=16)$ by enzyme-linked immunosorbent assay. The horizontal bars indicate the means. MADA, mandibuloacral dysplasia type A; MMP, matrix metalloproteinase; TIMP-2, tissue inhibitor of metalloproteinase 2 .

TNF- $\alpha$, IL- 6 and IL-1 $\beta$ have been detected in the serum of controls and MADA patients (TNF- $\alpha: 0.00934 \pm 0.004$ vs $0.015 \pm 0.0113 \mathrm{pg} /$ $\mathrm{ml}, \mathrm{p}=0.7308$; IL-6: $3.683 \pm 4.028$ vs $1.855 \pm$ $0.4824 \mathrm{pg} / \mathrm{ml}, \mathrm{p}=0.2198$ and IL-1 $\beta: 0.3344 \pm$ 0.6561 vs $0.5365 \pm 0.9979 \mathrm{pg} / \mathrm{ml}, \mathrm{p}=0.6$ ).

\section{Discussion}

Through a combination of biochemical assays, this report provides the first evidence that abnormalities in the maintenance of bone ECM homeostasis in MADA patients is associated to high levels of MMP-9 active form in patient's serum compared with controls. Even though this is not a proof of a prominent role played by MMP-9 in this process, it must be reminded that there is strong evidence that MMPs play a crucial role during osteogenesis and bone remodelling (32). Their synthesis by osteoblasts has been demonstrated during osteoid degradation prior to resorption of mineralized matrix by osteoclasts, and their activities are regulated by TIMPs (33). 
The process of bone remodelling is complex and requires 'coupling' between osteoclastic and osteoblastic activities. Disruption of the balance between osteoclast and osteoblast activities is observed in various disease states such as osteoporosis and bone destruction by metastatic tumours. The central step of bone resorption is the removal of bone matrix by osteoclasts. In this context, MMP-9 may act not only as a solubilizer of bone matrix but also as a regulator of initiation of bone resorption and coupling to bone formation (34-40). This possibility is supported by several observations under different physiological/ developmental situations and employing various experimental approaches, including proteinase inhibitor studies and transgenic mice. As a matter of fact, mice lacking MMP-9 accumulate hypertrophic cartilage within a growing region of their long bones and ultimately exhibit subtle bone shortening (41). Furthermore, upregulation of MMPs, in particular MMP-2 and -9, has been reported in many human bone-related disorders, as for instance several types of cancer-related osteolysis (42-47), osteoarthritis $(48,49)$, loosening of prosthesis (50), fracture healing (51), and periodontitis $(52,53)$. In particular, MMP-9 level was found elevated in arthritis, degrading noncollagen matrix components of the joints. MMP9 is also active in the control of hypertrophic cartilage vascularization and skeletal development as well as in bone resorption $(39,54,55)$. Thus, in recent years, both enzymes have received a great deal of attention as putative markers for clinical applications, that being mainly true for MMP-9, which is rarely expressed in adult human tissues, and it is almost always associated to inflammatory condition.

In our study, MADA serum levels of MMP-9 were markedly enhanced (4.7-fold over control level) $(\mathrm{p}<0.005)$, showing a considerable activity of this gelatinase with respect to the control serum. We revealed, by zymography, the presence of one band corresponding to high-molecular weight form of MMP-9, disulphide-bonded homodimeric form $(207 \mathrm{kDa})$, only in four of five $(80 \%)$ MADA patients. This form has been identified in a variety of pro-MMP-9-producing cells including normal (56-58) and tumour $(59,60)$ cells and in various biological fluids $(61,62)$ and tissues (63), indicating that this is a physiological form of the enzyme. In addition, we were also able to detect the gelatinolytic band corresponding to the $116 \mathrm{kDa}$ form representing the complex of MMP-9 with lipocalin (NGAL), which is usually present in neutrophil granules $(56,57)$. Probably their apparition could be linked to high serum levels of MMP-9 itself, as both these activity bands were undetectable in serum control. Accordingly, both bands were absent in one MADA patient, showing the minor level of total MMP-9 (Fig. 1a, line 6). However, the serum from MADA patients showed a slightly lower activity of the latent form of MMP-9 (i.e. proMMP-9) compared with control sera, suggesting that the activation process is more active in MADA patients than in healthy subjects.

We propose that such increase of MMP-9 in the serum of MADA patients indicates a participation of this enzyme to specific imbalance of the homeostasis process involving an altered bone ECM remodelling, increased bone resorption, and cartilage damage. This hypothesis is reinforced by the absence of alterations in MADA patients for serum levels of both other MMPs (i.e. MMP-2, -8 , and -13) and several other inflammatory markers (i.e. TNF- $\alpha$, IL-6, and IL-1 $\beta$ ). Notably, well-known activators of MMP-9 (such as MMP2 and -13) were in the normal concentration range, suggesting that the induced activity and expression of MMP-9 are not a consequence of the post-secretion activation mediated by these proteases (64). Similarly, no evidence for an incomplete inhibition through TIMPs was evident because the levels of TIMP-2 were detected at physiological levels. In addition, we have surprisingly found that the serum levels of stromelysin-1 (MMP-3) were significantly lower in MADA patients than in normal subjects. This is a very important observation because MMP-3 is one of the MMPs responsible for the activation of MMP-9, and the lower serum level of MMP-3 rules out the possibility that the increased activation of MMP-9 is a simple consequence of an enhanced activity of MMP-3. In this respect, this information strengthens the idea of a direct correlation between the enhanced activity of MMP-9 and the altered bone homeostasis, eliminating other indirect influences by the activity of other MMPs. This is a relevant assessment because it was previously suggested (65-68) that a high concentration and localization of MMP-3 in the joint tissues, such as cartilage and synovium, may contribute to cartilage degradation in patients with osteoarthritis. However, the inverse correlation between MMP-9 and -3 levels detected in MADA patients could reflect the presence in these patients of an inducible factor that regulates diametrically the expression of these enzymes. The identification of osteoclast-specific markers in these diseases is crucial in establishing clinical protocols using anti-resorptive drugs and to understand the genetic regulation of osteoclast development and function (69). Bone resorption in culturederived osteoclasts is inhibited by three resorption 
inhibitors: calcitonin, alendronate and an integrin antagonist (70). Bisphosphonates, for example form the mainstay of current therapy for a wide range of human bone diseases, including osteoporosis, rheumatoid arthritis, metastatic bone cancer and hypercalcaemia $(71,72)$. In this context, the availability of a disease-specific osteoclastic marker is considered to be required for a proper clinical trial using this class of drugs. Further development of in vitro assays for the direct assessment of osteoclast function in MADA cells will lead to improved clinical treatments for the bone disease observed in MADA patients, which constitute a major target of this complex disorder. To explore this further, it will be important to better define MMP-9 activation, inhibition, and deactivation processes in MADA cells. Such studies should shed additional light on the molecular mechanisms of laminopathies and enable to develop patient-appropriate therapies.

\section{Acknowledgements}

This work was supported by EU grant FP6 'Euro-laminopathies' no. 018690, Italian Istituto Superiore di Sanità 'Rare diseases Italy-USA program' grant no. 526/D30, and Italian Telethon and the Italian Space Agency.

\section{References}

1. Young LW, Radebaugh JF, Rubin P et al. New syndrome manifested by mandibular hypoplasia, acroosteolysis, stiff joints and cutaneous atrophy (mandibuloacral dysplasia) in two unrelated boys. Birth Defects Orig Artic Ser 1971: 7: 291-297.

2. Afifi HH, El-Bassyouni HT. Mandibuloacral dysplasia: a report of two Egyptian cases. Genet Couns 2005: 16: 353-362.

3. Novelli G, Muchir A, Sangiuolo F et al. Mandibuloacral dysplasia is caused by a mutation in LMNA encoding lamin A/C. Am J Hum Genet 2002: 71: 426-431.

4. Shen JJ, Brown CA, Lupski JR et al. Mandibuloacral dysplasia caused by homozygosity for the R $527 \mathrm{H}$ mutation in lamin A/C. J Med Genet 2003: 40: 854-857.

5. Garg A, Cogulu O, Ozkinay F et al. A novel homozygous Ala529Val LMNA mutation in Turkish patients with mandibuloacral dysplasia. J Clin Endocrinol Metab 2005: 90: 5259-5264.

6. Fisher DZ, Chaudhary N, Blobel G. cDNA sequencing of nuclear lamins $\mathrm{A}$ and $\mathrm{C}$ reveals primary and secondary structural homology to intermediate filament proteins. Proc Natl Acad Sci U S A 1986: 83 (17): 6450-6454.

7. Goldman RD, Gruenbaum Y, Moir RD et al. Nuclear lamins: building blocks of nuclear architecture. Genes Dev 2002: 16 (5): 533-547.

8. Kosho T, Takahashi J, Momose T et al. Mandibuloacral dysplasia and a novel LMNA mutation in a woman with severe progressive skeletal changes. Am J Med Genet A 2007: 143 (21): 2598-2603.

9. Simha V, Agarwal AK, Oral EA et al. Genetic and phenotypic heterogeneity in patients with mandibuloacral dysplasia-associated lipodystrophy. J Clin Endocrinol Metab 2003: 88: 2821-2824.

10. Smith ED, Kudlow BA, Frock RL et al. A-type nuclear lamins, progerias and other degenerative disorders. Mech Ageing Dev 2005: 126: 447-460.

11. Agarwal AK, Fryns JP, Auchus RJ et al. Zinc metalloproteinase, ZMPSTE24, is mutated in mandibuloacral dysplasia. Hum Mol Genet 2003: 12 (16): 1995-2001.

12. Bergo MO, Gavino B, Ross $\mathbf{J}$ et al. Zmpste24 deficiency in mice causes spontaneous bone fractures, muscle weakness, and a prelamin A processing defect. Proc Natl Acad Sci U S A 2002: 99 (20): 13049-13054.

13. Nagase H, Woessner JF Jr. Matrix metalloproteinases. J Biol Chem 1999: 274: 21491-21494.

14. Birkedal-Hansen H, Moore WG, Bodden MK et al. Matrix metalloproteinases: a review. Crit Rev Oral Biol Med 1993: 4: 197-250.

15. Fini ME, Cook JR, Mohan R et al. Regulation of matrix metalloproteinase gene expression. In: Parks WC, Mecham RP, eds. Matrix metalloproteinases. San Diego, CA: Academic Press 1998: 299-356.

16. Sternlicht MD, Werb Z. How matrix metalloproteinases regulate cell behaviour. Annu Rev Cell Dev Biol 2001: 17: 463-516.

17. Guo H, Li R, Zucker S, Toole BP. EMMPRIN (CD147), an inducer of matrix metalloproteinase synthesis, also binds interstitial collagenase to the tumor cell surface. Cancer Res 2000: 60: 888-891.

18. Zucker S, Hymowitz M, Conner C et al. Measurement of matrix metalloproteinases and tissue inhibitors of metalloproteinases in blood and tissues. Clinical and experimental applications. Ann N Y Acad Sci 1999: 878: 212-227.

19. Nagase H, Visse R, Murphy G. Structure and function of matrix metalloproteinases and TIMPs. Cardiovasc Res 2006: 69 (3): 562-573.

20. Vihinen P, Kähäri VM. Matrix metalloproteinases in cancer: prognostic markers and therapeutic targets. Int $\mathbf{J}$ Cancer 2002: 99: 157-166.

21. $\mathrm{Vu} \mathrm{TH}, \mathrm{Werb} \mathrm{Z}$. Matrix metalloproteinases: effectors of development and normal physiology. Genes Dev 2000: 14: 2123-2133.

22. Nakamura T, Ushiyama C, Suzuki S et al. Elevation of serum levels of metalloproteinase-1, tissue inhibitor of metalloproteinase-1and type IV collagen, and plasma levels of metalloproteinase-9 in polycystic kidney disease. Am J Nephrol 2000: 20: 32-36.

23. Young-Min SA, Beeton C, Laughton R et al. Serum TIMP1, TIMP-2 and MMP-1 in patients with systemic sclerosis, primary Raynaud's phenomenon, and in normal controls. Ann Rheum Dis 2001: 60: 846-851.

24. Klimiuk PA, Sierakowski S, Latosiewicz R et al. Serum matrix metalloproteinases and tissue inhibitors of metalloproteinases in different histological variants of rheumatoid synovitis. Rheumatology 2002: 41: 78-87.

25. Urbanski SJ, Edwards DR, Maitland A et al. Expression of metalloproteinases and their inhibitors in primary pulmonary carcinomas. Br J Cancer 1992: 66: 1188-1194.

26. Hrabec E, Strek M, Greger J et al. Matrix metalloproteinases in lung cancer. Curr Pneumol 1998: 2: 57-61.

27. Pyke C, Ralfkiaer E, Tryggvason K et al. Messenger RNA for two type IV collagenases is located in stromal cells in human colon cancer. Am J Pathol 1993: 142: 359-364.

28. Lee KS, Rha SY, Kim SJ et al. Sequential activation and production of matrix metalloproteinase-2 during breast cancer progression. Clin Exp Metastasis 1996: 14: 512-519.

29. Lombardi F, Gullotta F, Columbaro M et al. Compound heterozygosity for mutations in LMNA in a patient with 


\section{Increased level of MMP-9 in MADA disease}

a myopathic and lipodystrophic mandibuloacral dysplasia type A phenotype. J Clin Endocrinol Metab 2007: 92 (11): 4467-4471.

30. Woessner JF. Quantification of matrix metalloproteinases in tissue samples. Methods Enzymol 1992: 1 (425): 510-527.

31. Van den Steen PE, Dubois B, Nelissen I et al. Biochemistry and molecular biology of gelatinase $\mathrm{B}$ or matrix metalloproteinase-9 (MMP-9). Crit Rev Biochem Mol Biol 2002: 37: 375-536.

32. Mannello F, Tonti GA, Bagnara GP et al. Role and function of matrix metalloproteinases in the differentiation and biological characterization of mesenchymal stem cells. Stem Cells 2006: 24 (3): 475-481.

33. Hill PA, Murphy G, Docherty AJ et al. The effects of selective inhibitors of matrix metalloproteinases (MMPs) on bone resorption and the identification of MMPs and TIMP-1 in isolated osteoclasts. J Cell Sci 1994: 107: 30553064.

34. Okada Y, Naka K, Kawamura K et al. Localization of matrix metalloproteinase 9 (92-kilodalton gelatinase/type IV collagenase $=$ gelatinase $\mathrm{B}$ ) in osteoclasts: implications for bone resorption. Lab Invest 1995: 72 (3): 311-322.

35. Tezuka K, Nemoto K, Tezuka Y et al. Identification of matrix metalloproteinase 9 in rabbit osteoclasts. J Biol Chem 1994: 269 (21): 15006-15009.

36. $\mathrm{Vu} \mathrm{T}$, Werb Z. Gelatinase B: structure, regulation and function. In: Parks WC, Mecham RP, eds. Matrix metalloproteinases. San Diego, CA: Academic Press 1998: 115-148.

37. Wucherpfennig AL, Li YP, Stetler-Stevenson WG et al. Expression of $92 \mathrm{kD}$ type IV collagenase/gelatinase B in human osteoclasts. J Bone Miner Res 1994: 9: 549-556.

38. Inui $\mathrm{T}$, Ishibashi $\mathrm{O}$, Origane $\mathrm{Y}$ et al. Matrix metalloproteinases and lysosomal cysteine proteases in osteoclasts contribute to bone resorption through distinct modes of action. Biochem Biophys Res Commun 1999: 258: 173178.

39. Malemud CJ. Matrix metalloproteinases: role in skeletal development and growth plate disorders. Front Biosci 2006: 11: 1702-1715.

40. Delaissé JM, Engsig MT, Everts V et al. Proteinases in bone resorption: obvious and less obvious roles. Clin Chim Acta 2000: 291 (2): 223-234.

41. Vu TH, Shipley JM, Bergers G et al. MMP-9/gelatinase B is a key regulator of growth plate angiogenesis and apoptosis of hypertrophic chondrocytes. Cell 1998: 93 (3): 411-422.

42. Stamenkovic I. Extracellular matrix remodelling: the role of matrix metalloproteinases. J Pathol 2003: 200 (4): 448464.

43. Kawashima A, Okada Y, Nakanishi I et al. Immunolocalization of matrix metalloproteinases and tissue inhibitors of metalloproteinases in human chondrosarcomas. Gen Diagn Pathol 1997: 142: 129-137.

44. Himelstein BP, Asada N, Carlton MR et al. Matrix metalloproteinase (MMP-9) expression in childhood osseous osteosarcoma. Med Pediatr Oncol 1998: 31: 471-474.

45. Sasaguri Y, Komiya S, Sugama K et al. Production of matrix metalloproteinase 2 and 3 (stromelysin) by stromal cells and giant cell tumor of bone. Am J Pathol 1992: 141: 611-621.

46. Ueda Y, Imai K, Tsuchiya $\mathrm{H}$ et al. Matrix metalloproteinase 9 (gelatinase B) is expressed in multinucleated giant cells of human giant cell tumor of bone and is associated with vascular invasion. Am J Pathol 1996: 148: 611-622.

47. Schoedel KE, Greco MA, Stetler-Stevenson WG et al. Expression of metalloproteinases in giant cell tumor of bone: an immunohistochemical study with clinical correlation. Hum Pathol 1996: 27: 1144-1148.

48. Imai $\mathrm{K}$, Ohta $\mathrm{S}$, Matsumoto $\mathrm{T}$ et al. Expression of membrane-type 1 matrix metalloproteinase and activation of progelatinase A in human osteoarthritic cartilage. Am J Pathol 1997: 151: 245-256.

49. Ishiguro $\mathrm{N}$, Ito $\mathrm{T}$, Ito $\mathrm{H}$ et al. Relationship of matrix metalloproteinases and their inhibitors to cartilage proteoglycan and collagen turnover: analyses of synovial fluid from patients with osteoarthritis. Arthritis Rheum 1999: 41: 129-136.

50. Takagi M, Santavirta S, Ida H et al. The membrane-typematrix metalloproteinase/matrix metalloproteinase-2/tissue inhibitor of metalloproteinase-2 system in periprosthetic connective-tissue remodeling in loose total-hip prostheses. Lab Invest 1998: 78: 735-742.

51. Yamagiwa H, Tokunaga K, Hayami T et al. Expression of metalloproteinase-13 (collagenase-3) is induced during fracture healing in mice. Bone 1999: 25 (2): 197-203.

52. Birkedal-Hansen H. Role of matrix metalloproteinases in human periodontal diseases. J Periodontol 1993: 64: 474 484

53. Ingman $\mathrm{T}$, Sorsa $\mathrm{T}$, Lindy $\mathrm{O}$ et al. Multiple forms of gelatinases/type IV collagenases in saliva and gingival crevicular fluid of periodontitis patients. J Clin Periodontol 1994: 21: 26-31.

54. Martel-Pelletier J, Welsch DJ, Pelletier JP. Metalloproteases and inhibitors in arthritic diseases. Best Pract Res Clin Rheumatol 2001: 15 (5): 805-829.

55. Pelletier JP, Martel-Pelletier J, Abramson SB. Osteoarthritis, an inflammatory disease: potential implication for the selection of new therapeutic targets. Arthritis Rheum 2001: 44 (6): 1237-1247.

56. Kjeldsen L, Johnsen AH, Sengelov $\mathrm{H}$ et al. Isolation and primary structure of NGAL, a novel protein associated with human neutrophil gelatinase. J Biol Chem 1993: 268: 10425-10432.

57. Triebel S, Blaser J, Reinke $\mathrm{H}$ et al. A $25 \mathrm{kDa}$ alpha $2-$ microglobulin-related protein is a component of the 125 $\mathrm{kDa}$ form of human gelatinase. FEBS Lett 1992: 314: 386-388.

58. Toth M, Gervasi DC, Fridman R. Phorbol ester-induced cell surface association of matrix metalloproteinase- 9 in human MCF10A breast epithelial cells. Cancer Res 1997: 57: 3159-3167.

59. Wilhelm SM, Collier IE, Marmer BL et al. SV40transformed human lung fibroblasts secrete a $92-\mathrm{kDa}$ type IV collagenase which is identical to that secreted by normal human macrophages. J Biol Chem 1989: 264: 17213-17221.

60. Moll UM, Youngleib GL, Rosinski KB et al. Tumor promoter-stimulated $\mathrm{Mr} 92,000$ gelatinase secreted by normal and malignant human cells: isolation and characterization of the enzyme from HT1080 tumor cells. Cancer Res 1990: 50: 6162-6170.

61. Vartio T, Baumann M. Human gelatinase/type IV procollagenase is a regular plasma component. FEBS Lett 1989: 255: 285-289.

62. Mautino G, Oliver N, Chanez P et al. Increased release of matrix metalloproteinase-9 in bronchoalveolar lavage fluid and by alveolar macrophages of asthmatics. Am J Respir Cell Mol Biol 1997: 17: 583-591.

63. Upadhya AG, Harvey RP, Howard TK et al. Evidence of a role for matrix metalloproteinases in cold preservation injury of the liver in humans and in the rat. Hepatology 1997: 26: 922-928. 


\section{Lombardi et al.}

64. Vempati P, Karagiannis ED, Popel AS. A biochemical model of matrix metalloproteinase 9 activation and inhibition. J Biol Chem 2007: 282 (52): 37585-37596.

65. Hasty KA, Reife RA, Kang $\mathrm{AH}$ et al. The role of stromelysin in the cartilage destruction that accompanies inflammatory arthritis. Arthritis Rheum 1990: 33: 388-397.

66. Konttinen YT, Ainola M, Valleala H et al. Analysis of 16 different matrix metalloproteinases (MMP-1 to MMP-20) in the synovial membrane: different profiles in trauma and rheumatoid arthritis. Ann Rheum Dis 1999: 58 (11): 691-697.

67. Yoshihara Y, Nakamura H, Obata K et al. Matrix metalloproteinases and tissue inhibitors of metalloproteinases in synovial fluids from patients with rheumatoid arthritis or osteoarthritis. Ann Rheum Dis 2000: 59 (6): 455-461.
68. Okada Y, Shinmei M, Tanaka O et al. Localization of matrix metalloproteinase 3 (stromelysin) in osteoarthritic cartilage and synovium. Lab Invest 1992: 66: 680-690.

69. Teitelbaum SL, Ross FP. Genetic regulation of osteoclast development and function. Nat Rev Genet 2003: 4 (8): 638-649.

70. Bilezikian JP, Raisz LG, Rodan GA, eds. Principles of bone biology, 2nd edn. San Diego: Academic Press 2001: 1031-1045.

71. Jordan N, Barry M, Murphy E. Comparative effects of antiresorptive agents on bone mineral density and bone turnover in postmenopausal women. Clin Interv Aging 2006: 1 (4): 377-387.

72. Costa L Bisphosphonates: reducing the risk of skeletal complications from bone metastasis. Breast 2007: 16-20. 